\title{
Multi-scale assessment of human-induced changes to Amazonian instream habitats
}

\author{
Cecília G. Leal · Paulo S. Pompeu • Toby A. Gardner • Rafael P. Leitão • \\ Robert M. Hughes - Philip R. Kaufmann • Jansen Zuanon • \\ Felipe R. de Paula - Silvio F. B. Ferraz • James R. Thomson • \\ Ralph Mac Nally $\cdot$ Joice Ferreira $\cdot$ Jos Barlow
}

Received: 22 March 2015/ Accepted: 14 March 2016/Published online: 14 June 2016

(C) The Author(s) 2016. This article is published with open access at Springerlink.com

\begin{abstract}
Context Land use change and forest degradation have myriad effects on tropical ecosystems. Yet their consequences for low-order streams remain very poorly understood, including in the world́s largest freshwater basin, the Amazon.

Objectives Determine the degree to which physical and chemical characteristics of the instream habitat of low-order Amazonian streams change in response to past local- and catchment-level anthropogenic disturbances.
\end{abstract}

Electronic supplementary material The online version of this article (doi:10.1007/s10980-016-0358-x) contains supplementary material, which is available to authorized users.

C. G. Leal $(\bowtie) \cdot$ P. S. Pompeu

Fish Ecology Laboratory, Federal University of Lavras, Lavras, MG 37200-000, Brazil

e-mail: c.gontijoleal@gmail.com

C. G. Leal $\cdot$ J. Barlow

Lancaster Environment Centre, Lancaster University, Lancaster LA1 4YW, UK

C. G. Leal · J. Barlow

Museu Paraense Emílio Goeldi, Belém, PA 66040-170, Brazil

T. A. Gardner

Stockholm Environment Institute, 10451 Stockholm, Sweden

R. P. Leitão · J. Zuanon

National Institute for Amazonia Research, Manaus, AM 69060-001, Brazil
Methods To do so, we collected field instream habitat (i.e., physical habitat and water quality) and landscape data from 99 stream sites in two eastern Brazilian Amazon regions. We used random forest regression trees to assess the relative importance of different predictor variables in determining changes in instream habitat response variables.

Results Multiple drivers, operating at multiple spatial scales, were important in determining changes in the physical habitat and water quality of the sites. Although we found few similarities in modelled relationships between the two regions, we observed non-linear responses of specific instream

\section{R. M. Hughes}

Amnis Opes Institute and Department of Fisheries \& Wildlife, Oregon State University, Corvallis, OR 97701, USA

P. R. Kaufmann

Office of Research and Development, U.S. Environmental Protection Agency, Corvallis, OR 97333, USA

F. R. de Paula - S. F. B. Ferraz

Forest Hydrology Laboratory (LHF), "Luiz de Queiroz"

College of Agriculture, University of São Paulo,

Piracicaba, SP 13418-900, Brazil

J. R. Thomson · R. Mac Nally

Institute for Applied Ecology, The University of Canberra, Bruce, ACT 2617, Australia 
characteristics to landscape change; for example $20 \%$ of catchment deforestation resulted in consistently warmer streams.

Conclusions Our results highlight the importance of local riparian and catchment-scale forest cover in shaping instream physical environments, but also underscore the importance of other land use changes and activities, such as road crossings and upstream agriculture intensification. In contrast to the propertyscale focus of the Brazilian Forest code, which governs environmental regulations on private land, our results reinforce the importance of catchment-wide management strategies to protect stream ecosystem integrity.

Keywords Anthropogenic impacts - Physical and chemical habitat $\cdot$ Random forest models - Watershed management · Deforestation - Land use change ·

Freshwater · Amazon basin - Tropical forest

\section{Introduction}

Land-use change (LUC) is one of the most important factors altering Earth's ecosystems (Vörösmarty and Shagian 2000; Foley et al. 2005; Ellis 2011) affecting both global biodiversity (Butchart et al. 2010; Tedesco et al. 2013; Newbold et al. 2015) and the conservation of ecosystem services (Millennium Ecosystem Assessment 2005; Russi et al. 2013). The impacts of LUC are of great concern in the tropics, where the expansion of agricultural and infrastructure development usually occur at the expense of species rich natural habitats (Davidson et al. 2012; Ferreira et al. 2014). While our understanding of the impacts of LUC on terrestrial tropical systems has improved significantly in recent decades (Malhi et al. 2014), tropical aquatic systems have received far less research attention, with the majority of existing work concentrated in a small number of well-studied regions, such as Costa Rica, Puerto Rico, Hong Kong and Australia (Dudgeon 2008).

Recent studies in tropical environments provide mounting evidence that LUC impacts on stream hydrobiogeochemistry can extend far beyond the

\section{J. Ferreira}

Embrapa Amazônia Oriental, Belém, PA 66095-903, Brazil adjacent forest. Terrestrial-aquatic links occur across multiple landscape scales (Uriarte et al. 2011) and pathways (e.g. groundwater flow and surface runoff) (Neill et al. 2006), and impacts on small watercourses can result in cascading effects on larger river networks (Neill et al. 2013). The conversion of forests into pasture and croplands is leading to manifold consequences for stream environments, such as degraded water quality (temperature and nutrient concentrations), excess sediments, and altered flow regimes (Neill et al. 2001; Davidson et al. 2004; Neill et al. 2006; Figueiredo et al. 2010; Neill et al. 2011; Macedo et al. 2013; Neill et al. 2013). These changes can have marked impacts on the biotic communities of streams, such as the negative effects of water temperature increases on many aquatic groups (Lorion and Kennedy 2008, 2009; Isaak et al. 2011; Thomson et al. 2012).

However, one major aspect of the ecology of tropical aquatic systems remains poorly studied, namely, the vulnerability of the physical habitat and water properties in low-order streams to LUC (Casatti et al. 2006a; Dudgeon 2008). Stream physical habitat includes a suite of characteristics and features of the abiotic environment such as habitat volume and stream size, habitat complexity and cover for aquatic biota, streambed particle size, bed stability, channelriparian and floodplain interaction, hydrologic regime and the condition and extent of the riparian vegetation (Kaufmann et al. 1999). Together with water properties (e.g. pH, conductivity etc.) these constitute the lotic environment of streams (hereafter called instream habitat).

Changes in instream habitat are ecologically important as they are likely to provide insights into stream integrity, and their ability to conserve biodiversity and maintain provision of ecosystem services. In temperate zones, aspects of the instream habitat are often used to detect and monitor LUC effects on stream condition (Kaufmann et al. 1999; Hughes et al. 2006). For example, observed impacts include bank erosion and sedimentation, alterations in discharge, reduced amount of wood, and increases in light incidence (Gregory et al. 1991; Allan et al. 1997; Sutherland et al. 2002; Allan 2004; Hughes et al. 2006; Beschta et al. 2013; Yeakley et al. 2014). Increases in the proportion of fine sediments can reduce the availability of food resources and habitat for fish and invertebrates by covering hard substrates and filling 
interstitial spaces (Nerbonne and Vondracek 2001). In addition, the loss of riparian vegetation that often accompanies stream degradation can have a negative impact on the provision of key ecosystem services, such as the buffering of flood waters, the maintenance of water flow during dry periods, and maintenance of water quality through natural filtration and treatment (Gregory et al. 1991; Millennium Ecosystem Assessment 2005; Brauman et al. 2007).

In general terms, the responses of tropical instream habitat to LUC are likely to mirror those of temperate streams because key processes are governed by similar hydraulic mechanisms. For example, changes in channel substrate are influenced by a combination of stream slope, geology, discharge, river bedform, and the presence of large wood and other organic materials (Mac Nally et al. 2011). However, the specific nature of such relationships may be different in tropical regions characterized by recent deforestation, rapid increases in agricultural mechanization, and high levels of river fragmentation from poorly planned infrastructure developments. These anthropogenic differences are overlain upon the distinct natural characteristics of many tropical streams (e.g. high water temperatures relative to similar elevations at other latitudes, high levels of hydrological periodicity with intense rainfall and runoff, distinct structural features of tropical vegetation) and high natural environmental heterogeneity (Junk and Wantzen 2004; Ortiz-Zayas et al. 2005; Boulton et al. 2008; Boyero et al. 2009). Natural regional differences are reflected in regional instream habitat and biological differences in tropical (Pinto et al. 2009; Uriarte et al. 2011; Macedo et al. 2014) and temperate (Whittier et al. 1988; Allan et al. 1997; Hughes et al. 2006) streams. A major research challenge therefore, is to untangle how rapidly changing disturbance processes interact with high levels of natural environmental heterogeneity to influence the structure and diversity of tropical stream habitats in different regions and over gradients of LUC (Ramírez et al. 2008; Boyero et al. 2009).

To address these issues, we conducted the first large-scale assessment of effects of LUC on instream habitat on streams in the Amazon, the world́s largest river basin, also containing the largest remaining area of continuous tropical forest. A main contribution and novelty of this study is the provision of the first systematic and detailed assessment of the physical habitat of small tropical streams, going beyond current understanding which is largely restricted to measures of water quantity and quality, and nutrient dynamics. We focus on small streams as they receive much less research attention and conservation interest compared to major river channels yet are thought to be the most diverse and extensive ecosystem type in the Amazon basin (Junk 1983; McClain and Elsenbeer 2001; Castello et al. 2013). Our study encompassed 99 stream sites spread across two frontier regions (Gardner et al. 2013). Those regions are typical of many tropical forested landscapes as they are threatened by myriad human activities including agricultural expansion, increases in the frequency and intensity of wildfires, large infrastructure developments (particularly dams and mining), the unsustainable extraction of timber and other forest products, and an unknown number of small dams in small streams resulting from road construction or built to provide water for cattle (Asner et al. 2005; Morton et al. 2006; Peres and Palacios 2007; Fearnside and Pueyo 2012; Castello et al. 2013; Macedo et al. 2013; Ferreira et al. 2014). Specifically, we ask: (1) What are the relationships among natural controls (e.g., catchment size and slope) and anthropogenic disturbances (e.g., road crossings, mechanized agriculture, and deforestation) that influence instream habitat? (2) Which landscape characteristics best explain variation in instream habitat condition? (3) How do relationships between landscape characteristics and instream habitat condition differ regionally?

\section{Methods}

\section{Study system}

We studied two regions in the eastern Brazilian Amazon state of Pará as part of the Sustainable Amazon Network (Rede Amazônia Sustentável, RAS), a multidisciplinary research initiative focused on investigating both the social and ecological dimensions of land use sustainability (Gardner et al. 2013). The Santarém region, including the municipalities of Santarém, Belterra and, Mojuí dos Campos (hereinafter 'STM') is located southeast of the Amazonas and Tapajós Rivers confluence. The second region, Paragominas ('PGM'), is in the lower Amazon Basin. Our sampling design included 48 small stream 
sites (1st to 3rd Strahler order on a digital 1:100,000 scale map) in STM, draining to the Curuá-Una River basin (36 sites) or directly to the Amazonas (6) or Tapajós Rivers (6); and 51 in PGM, encompassing the Gurupi (24) and Capim (27) River Basins (Fig. 1). Stream sites were distributed along a gradient of previously known anthropogenic impact based primarily on the amount of remnant forest cover in the upstream catchment of each site (Gardner et al. 2013).
Including two different regions with more than one million hectares each, offers confidence in confirming the general relevance of observed patterns and the relative importance of local and regional drivers (Gardner et al. 2013).

The two regions have different histories of human land use and occupation. STM (ca 1 million ha) has been occupied by Europeans since 1661, whereas PGM (ca 1.9 million ha) was formally established in
Fig. 1 Methodological framework to investigate the response of instream habitat of low-order Amazonian stream sites to local and landscape-scale human disturbances (see Table 1). Q1, Q2 and Q3 are the research questions referred to in the Introduction; Asterisk (*) see section "Selection of response variables" for the detailed process

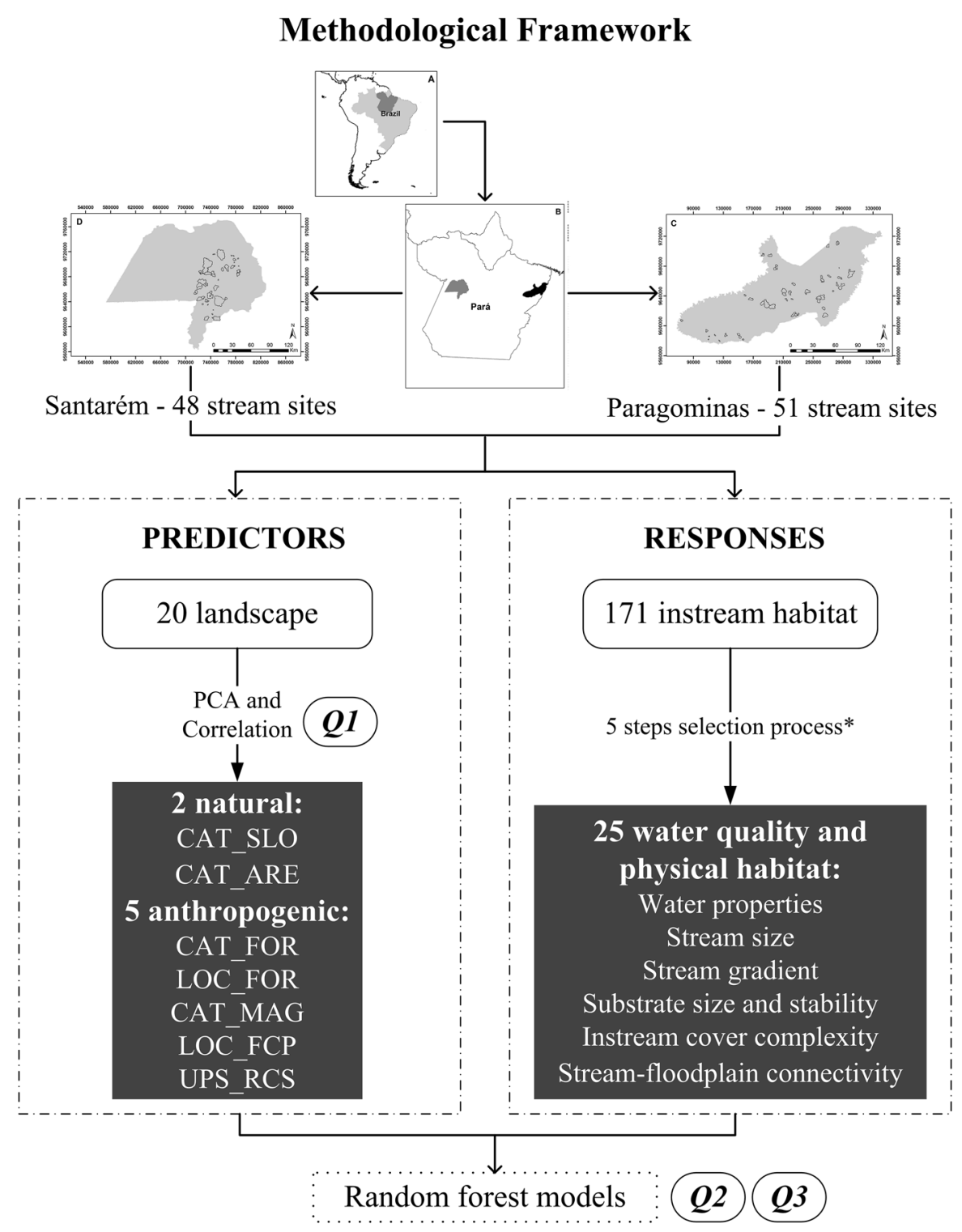


1959. Both regions have been bisected by federal highways first established in the 1960s and 1970s, with cascading influences on regional development. Since 2005 both exhibit decreasing rates of primary vegetation deforestation and today can be characterized as a diverse patchwork of mechanized agriculture, local and regional centres for cattle markets, silviculture (mostly Eucalyptus spp. and Schizolobium amazonicum, especially in PGM), densely populated smallholder colonies and agrarian reform settlements, as well as undisturbed and disturbed primary forests and regenerating secondary forests (Gardner et al. 2013).

\section{Sampling}

\section{Landscape predictor variables}

Landscape influences on instream condition occur at multiple spatial scales, usually represented in three main levels: upstream areas that have indirect connections with the stream channel (i.e., the catchment), the upstream riparian zone, and areas that have immediate contact with the channel (Allan et al. 1997; Wang et al. 2006a). Following this rationale we included these spatial scales (Fig. 2a): (1) the whole catchment upstream from the stream site (catchment); (2) the $100 \mathrm{~m}$ buffer along the entire drainage network upstream from the stream site (riparian network); and
(3) a $100 \mathrm{~m}$ riparian buffer along the sampled stream site only (local riparian). Catchment boundaries, mean elevation, and slope were obtained from digital elevation models for STM (SRTM images with $90 \mathrm{~m}$ resolution; Jarvis et al. 2008) and PGM (TopoData with 30 m resolution; Valeriano and Rossetti 2012). The drainage network was constructed using the hydrological model ArcSWAT (Di Luzio et al. 2004) for both regions.

Catchment area and catchment slope were used as natural control variables. Other relevant natural controls were not included because they varied very little across the studied area or sampling period. Nearly all stream sites (i.e. $97 \%$ in STM and $100 \%$ in PGM) were in catchments dominated by yellow latisol or yellow argisoil. Both types of soil are derived from sedimentary clay or sandy-clay materials from the low plateaus of the Amazon region related to the "Alter-doChão formation' (Embrapa 2006). Total precipitation during the sampling period was $250 \mathrm{~mm}$ in PGM and $260 \mathrm{~mm}$ STM, which represent $<15 \%$ of the mean annual values for these regions (1800-2100 mm) (Acker and Leptoukh 2007). Moreover we did not find considerable spatial variation in precipitation within each region, and we therefore considered that differences among stream sites are minor. Altitude range was also very similar in both regions, 46-170 m (136 m mean) in STM and 60-200 m (134 m mean) in PGM.
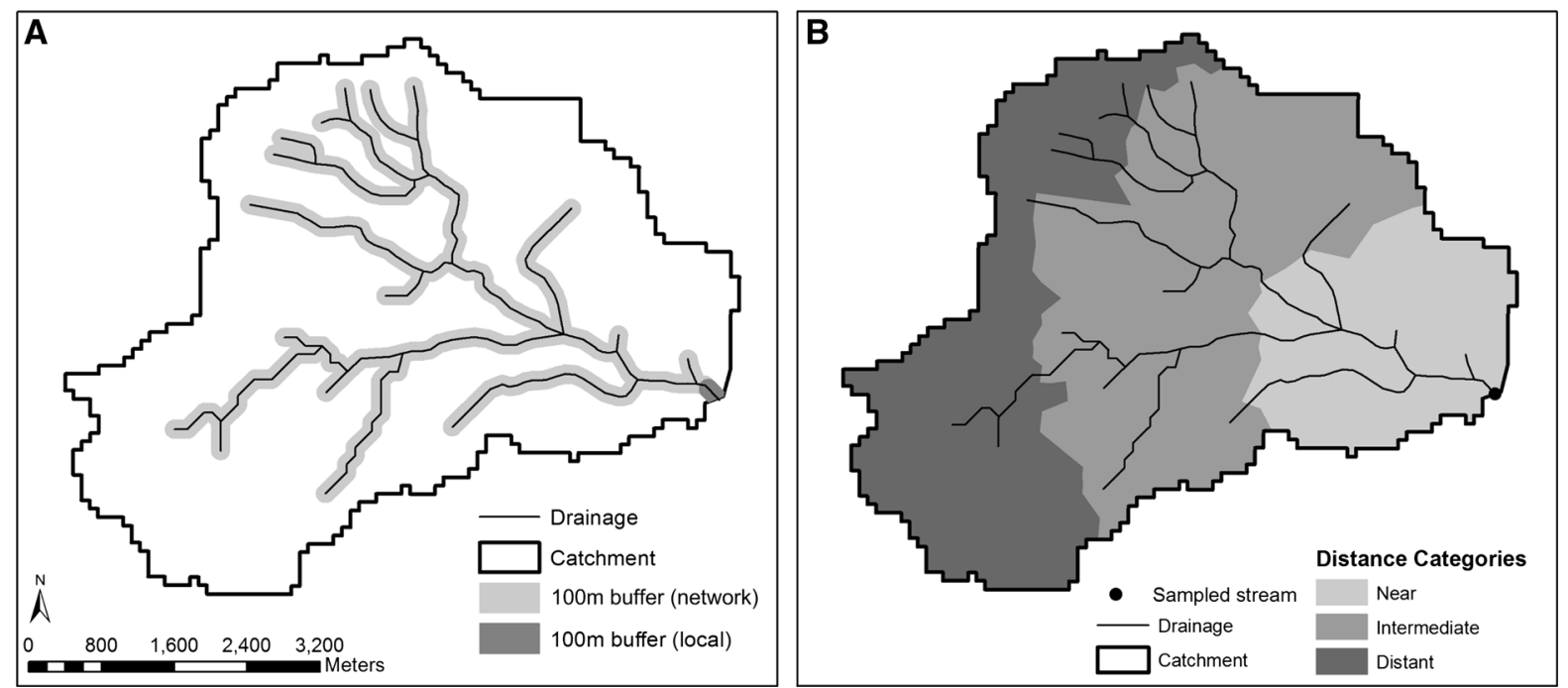

Fig. 2 Schematic of the spatial scales (a) and hydrological distances (b) considered to obtain the landscape predictor variables of instream habitat of Amazonian stream sites 
We estimated percentage of forest cover in each of the three spatial scales from a land use map (Landsat TM and ETM+ images, $30 \mathrm{~m}$ resolution, year 2010) (Gardner et al. 2013; Table 1). Forest included primary forest (whether undisturbed or showing signs of disturbance from fire or logging), and secondary forest older than 10 years (considered sufficiently developed to provide significant hydrological services based on our expert assessments). To calculate forest cover at different hydrological distances from the stream site as proposed by Paula et al. (2013), we first standardized the distances by the maximum distance in each catchment to account for differences in catchment size. Then we assigned all pixels in each catchment into near, intermediate, or distant categories and then calculated the percent forest cover in each of the distance categories (Fig. 2b).
Landscape variables that encompass historical land use are important indicators of stream integrity (Gergel et al. 2002; Uriarte et al. 2011). We estimated the history of mechanized agriculture from annual MODIS data from 2001 to 2010 (Gardner et al. 2013). Two other historical land use indicators were calculated for catchments by using a time-series of land use maps for the last two decades (following Ferraz et al. 2009): forest change curvature profile (FCCP) representing historical deforestation pattern and land-use intensity index (LUI) representing the mean time since deforestation. FCCP is calculated based on changes in forest proportion over time and it represents the maximum deviation of observed changes in forest proportion relative to a linear model between initial and final levels of forest cover. This index of historical landscape change captures relative differences among

Table 1 Candidate natural and anthropogenic landscape variables used to predict Amazonian instream habitat condition. Selected variables in bold

\begin{tabular}{|c|c|c|c|}
\hline Landscape & Acronym & Spatial scale & Definition \\
\hline \multicolumn{4}{|l|}{ Natural } \\
\hline Area & CAT_ARE & Catchment & Catchment area \\
\hline Slope & CAT_SLO & Catchment & Catchment slope \\
\hline \multicolumn{4}{|l|}{ Anthropogenic } \\
\hline \multirow[t]{4}{*}{ Land use } & CAT_FOR & Catchment & $\%$ Forest \\
\hline & NET_FOR & Network riparian & $\%$ Forest \\
\hline & LOC_FOR & Local riparian & $\%$ Forest \\
\hline & CAT_MAG & Catchment & $\%$ Mechanized agriculture \\
\hline \multirow[t]{6}{*}{ Hydrological distance to forest } & CAT_FOR_N & Catchment & $\%$ Forest "near" the stream site \\
\hline & CAT_FOR_I & Catchment & $\%$ Forest "intermediate" to the stream site \\
\hline & CAT_FOR_D & Catchment & $\%$ Forest "distant" from the stream site \\
\hline & NET_FOR_N & Network riparian & $\%$ Forest "near" the stream site \\
\hline & NET_FOR_I & Network riparian & $\%$ Forest "intermediate" to the stream site \\
\hline & NET_FOR_D & Network riparian & $\%$ Forest "distant" from the stream site \\
\hline \multirow[t]{6}{*}{ Historical land use indicators } & CAT_FCP & Catchment & Forest change curvature profile index (FCCP) \\
\hline & CAT_LUI & Catchment & Land-use intensity index (LUI) \\
\hline & NET_FCP & Network riparian & Forest change curvature profile index (FCCP) \\
\hline & NET_LUI & Network riparian & Land-use intensity index (LUI) \\
\hline & LOC_FCP & Local riparian & Forest change curvature profile index (FCCP) \\
\hline & LOC_LUI & Local riparian & Land-use intensity index (LUI) \\
\hline \multirow[t]{2}{*}{ Stream network fragmentation } & UPS_RCS & Catchment & $\begin{array}{l}\text { Number of road crossings within a } 5 \mathrm{~km} \\
\text { circular buffer upstream of the stream site } \\
\text { divided by catchment area }\end{array}$ \\
\hline & DWS_RCS & Catchment & $\begin{array}{l}\text { Number of road crossings within a } 5 \mathrm{~km} \text { circular } \\
\text { buffer downstream of the stream site divided by } \\
\text { catchment area }\end{array}$ \\
\hline
\end{tabular}


landscapes as to the timing of deforestation. FCCP was initially devised to assess differences in past deforestation trajectories in fragmented landscapes (Ferraz et al. 2014). Both FCCP and LUI were calculated using Land Use Change Analysis Tools (LUCAT), an open source ArcGIS extension (Ferraz et al. 2011, 2012).

We estimated riverscape fragmentation using the number of upstream (UPS_RCS) and downstream (DWS_RCS) road crossings within a $5 \mathrm{~km}$ circular buffer from the stream site. The road crossings in the drainage network were identified by aerial image interpretation using georeferenced colour Rapideye images (2010 for STM and 2011 for PGM, $5 \mathrm{~m}$ resolution). To map these crossings, we identified linear features in the images that cross the drainage network (Jensen 2000). A subset of half of these identified crossings were validated using Google Earth images. All landscape analyses were conducted in ArcGIS 9.3 (Environmental Systems Research Institute, Redlands, CA, USA).

\section{Instream habitat response variables}

For each site, we sampled stream physical habitat and water quality variables during the Amazonian dry season in STM (July-August 2010) and PGM (JuneAugust 2011). We measured dissolved oxygen, conductivity, $\mathrm{pH}$, and temperature with a digital portable meter placed below the water surface in the centre of the stream site before taking measurements inside the channel to prevent disturbance.

Each $150 \mathrm{~m}$ long stream site was subdivided into 10 continuous sections, $15 \mathrm{~m}$ long, by 11 cross-sectional transects (Fig. S1). We measured physical characteristics and features of the habitats following Peck et al. (2006) and Hughes and Peck (2008). The measurements were made at varying levels of resolution across sections and transects, but the response variables were all analysed as stream site summaries (e.g., means, percentages or maxima). For instance thalweg depth observations were made at very tightly spaced intervals; whereas channel cross-sections for observing large wood and streamside plots for observing riparian vegetation were spaced further apart. These varying levels of resolution of field measurements were found to reduce site measurement variances for the parameters of interest, yet facilitate completion of the measurements in $2-3 \mathrm{~h}$ by a two-person team regardless of ecoregion (Kaufmann et al. 1999; Peck et al. 2006; Hughes and Peck 2008).

For each section, we took 10 longitudinal equidistant measurements of thalweg depth and presence of fine sediments; visual quantification of bars, backwaters, side channels, and channel type (pool, glide, riffle, rapid, cascade, waterfall or dry channel); channel slope (measured with a flexible, water-filled plastic tube); and sinuosity (measured from compass bearings). We also recorded the presence of large wood of various size classes in or above the bankfull channel of the site.

For each of the 11 cross-sectional transects, we measured depth and made visual observations along five equidistant points transverse to the long axis of the stream to calculate mean depth, standard deviation of depth and the areal cover of various substrate types (bedrock, concrete, boulder, cobble, coarse gravel, fine gravel, sand, silt and clay, hardpan, fine litter, coarse litter, wood, roots, macrophyte, and algae). Transect characterization also included bankfull width and depth, wetted width and mean depth, incision height, undercut bank distance, and bank angle. We assessed habitat complexity at each transect in $10 \mathrm{~m}^{2}$ plots inside the stream channel, using visual estimates of the areal cover of filamentous algae, aquatic macrophytes, leaf packs, roots, large wood $>30 \mathrm{~cm}$ diameter, brush and small wood, overhanging vegetation $<1 \mathrm{~m}$ above the water surface, undercut banks, boulders, and artificial structures. We measured vegetation canopy cover above the channel with a densiometer at the centre of each transect by facing upstream, downstream, left and right, as well as by facing both banks near the banks. We calculated discharge from mean current velocity (estimated from the travel time of a floating object along three known distances) and mean cross-sectional area (measured as mean depth times mean width of the three known distances) of the site.

From this suite of field measurements, we calculated an initial set of 171 instream habitat variables from the field data based on Kaufmann et al. (1999), including 25 channel morphology, 16 channel unit, 5 channel sinuosity and slope, 28 substrate size and composition, 33 habitat complexity, 60 large wood, and 4 stream canopy cover variables. Geometric mean substrate diameter and relative bed stability were also calculated (Kaufmann et al. 2008). 
Data analysis

\section{Selection of landscape predictor variables}

Given the hierarchical nature of the land-use predictor variables (catchment scale encompasses network riparian which encompasses local riparian scale), we expected high levels of correlation among them. To limit redundancy and to produce a smaller set of the most representative variables of human-associated disturbances, we first conducted a principal components analysis (PCA) to identify variables most distinguishing the landscape disturbance characteristics of different stream sites. We then excluded other variables that were highly correlated with those measures $\left(r_{\text {Pearson }}>0.7\right)$. In the selection process we aimed to keep at least one predictor variable from the main groups of anthropogenic indicators (Table 1), for instance land use cover, historical land use, and riverscape fragmentation. These preliminary analyses were also used to answer our first research question.

\section{Selection of instream habitat response variables}

From the set of 171 instream habitat response variables, we selected a smaller set for further analysis, ensuring that we included measures for each key aspect of stream physical habitat (according to Kaufmann et al. 1999): stream size, stream gradient, substrate size and stability, instream cover complexity, and stream-floodplain connectivity. Our selection process involved eliminating variables that (i) had more than $90 \%$ of zero values $(n=25)$, (ii) were highly correlated with other variables $\left(r_{\text {Pearson }}>0.7\right)$ and (iii) represented similar underlying information as other variables (e.g. number and volume of wood or proportion and count of an individual substrate size). We also combined variables that represented closely related features (e.g. \%sand substrate and \% fine combined into \%sand + fine). Finally we used our specialist judgement to select a final set of 21 physical habitat variables. The 21 physical habitat variables and the four water quality variables yielded the set of 25 instream habitat response variables (Table 2; S1).

\section{Relationships between LUC and instream habitat}

To evaluate how neighbouring LUC influences instream habitat, we modelled instream habitat
Table 2 Acronyms and definitions of instream habitat (water quality and physical habitat features) response variables of Amazonian streams

\begin{tabular}{|c|c|}
\hline $\begin{array}{l}\text { Instream } \\
\text { habitat }\end{array}$ & Definition \\
\hline \multicolumn{2}{|c|}{ Water quality } \\
\hline TEMP & Water temperature $\left({ }^{\circ} \mathrm{C}\right)$ \\
\hline DO & Dissolved oxygen (mg/L) \\
\hline $\mathrm{PH}$ & $\mathrm{pH}$ \\
\hline COND & Electrical conductivity $(\mu \mathrm{S} / \mathrm{cm})$ \\
\hline \multicolumn{2}{|c|}{ Physical habitat } \\
\hline \multicolumn{2}{|l|}{ Substrate } \\
\hline FINE & $\begin{array}{l}\text { Streambed surficial fines }<0.6 \mathrm{~mm} \text { diameter }(\% \text { areal } \\
\text { cover) }\end{array}$ \\
\hline SAFN & $\begin{array}{l}\text { Streambed surficial sand }+ \text { fines }<2 \mathrm{~mm} \text { diameter }(\% \\
\text { areal cover) }\end{array}$ \\
\hline FNGR & $\begin{array}{l}\text { Streambed surficial fine gravel } 2-16 \mathrm{~mm} \text { diameter (\% } \\
\text { areal cover) }\end{array}$ \\
\hline BIGR & $\begin{array}{l}\text { Streambed surficial substrate coarse gravel and larger } \\
\quad(>16 \mathrm{~mm} \text { diameter })(\% \text { areal cover })\end{array}$ \\
\hline $\mathrm{D}_{\mathrm{gm}}$ & $\begin{array}{l}\log _{10} \text { streambed substrate particle geometric mean } \\
\text { diameter (mm) (Kaufmann et al. 2008) }\end{array}$ \\
\hline \multicolumn{2}{|c|}{ Cover and wood } \\
\hline $\mathrm{AMCV}$ & In-channel algae and macrophytes (\% areal cover) \\
\hline NTCV & $\begin{array}{l}\text { In-channel natural cover (wood, live trees and roots, leaf } \\
\text { packs, overhanging vegetation, undercut banks, } \\
\text { boulders) ( } \% \text { areal cover) }\end{array}$ \\
\hline WOOD & Wood volume $\left(\mathrm{m}^{3} / \mathrm{m}^{2}\right.$ wetted channel area) \\
\hline \multicolumn{2}{|c|}{ Channel morphology } \\
\hline WDDP & Mean wetted width $\times$ thalweg depth $\left(\mathrm{m}^{2}\right)$ \\
\hline DPTH & Standard deviation of thalweg depth $(\mathrm{cm})$ \\
\hline THDP & Thalweg depth ratio at bankfull/low flow (dimensionless) \\
\hline BKAN & Standard deviation of bank angle (\%) \\
\hline BKWD & $\begin{array}{l}\text { Ratio: bankfull width to bankfull thalweg depth } \\
\text { (dimensionless) }\end{array}$ \\
\hline RP100 & Mean residual depth at thalweg $(\mathrm{cm})$ \\
\hline SINU & Channel sinuosity (dimensionless) \\
\hline SLOP & Channel slope $(\%)$ \\
\hline FAST & $\begin{array}{l}\text { Channel fast water }(\% \\
\text { riffle }+ \text { rapid }+ \text { cascade }+ \text { waterfall })\end{array}$ \\
\hline \multicolumn{2}{|l|}{ Other } \\
\hline $\mathrm{DSCH}$ & Low flow season discharge measured in the field $\left(\mathrm{m}^{3} / \mathrm{s}\right)$ \\
\hline LRBS & $\begin{array}{l}\log _{10} \text { of relative bed stability (dimensionless) estimated } \\
\text { at bankfull flow conditions (Kaufmann et al. } \\
\text { 2008, 2009) }\end{array}$ \\
\hline LDMB & $\begin{array}{l}\log _{10} \text { of critical substrate diameter (maximum mobile } \\
\text { diameter mm) at bankfull flow conditions (Kaufmann } \\
\text { et al. 2008, 2009) }\end{array}$ \\
\hline SHAD & Canopy density (shading) measured at mid-channel (\%) \\
\hline
\end{tabular}

variables as functions of anthropogenic and natural control predictor variables. We used random forest models (RF; Breiman 2001), which model complex interactive and non-linear response-predictor 
relationships, and have excellent predictive performance (Prasad et al. 2006; Smith et al. 2011). Because the Amazon is a complex system about which relatively little is known, we employed a flexible modelling framework like RF that can accommodate, and reveal, complex interactions and non-linear effects. In general, we have much more confidence that relationships revealed by such an analyses are real if the models have good predictive capacity. RFs produce an ensemble of regression trees, where each tree is fitted to a bootstrap sample of the data, and each partition within a tree is split on a random subset of the predictor variables (Ellis et al. 2012). The data not used to build a tree in each bootstrap sample, called the out-of-bag (OOB) sample, is used to calculate crossvalidation performance statistics and measures of variable importance (Ellis et al. 2012). RF calculates a pseudo- $r^{2}$ value as $1-$ MSE/Var(y), where MSE is the mean squared error of the out of bag predictions (Ellis et al. 2012). That value estimates the proportion of variation that can be reliably predicted by the ensemble model. The relative importance (RI) of individual variables was calculated as the mean percentage increase in MSE when a variable was randomly permuted, which used the conditional permutation method in the $\mathrm{R}$ 'extendedForest' library (Smith et al. 2011) to reduce bias when predictors are correlated. Conditional RI values were computed from the conditional permutation distribution of each variable, permuted within three partitions of correlated $\left(r_{\text {Pearson }}>0.5\right)$ variables (see Ellis et al. 2012). RI values were used to build partial dependence plots. All models were fitted with 10,000 trees, with one-third of the variables randomly sampled as candidates at each split (one variable selected if total variables $<3$ ). Variables with negative relative importance values, which do not contribute to the overall explanation, were excluded from final models.

We fitted three RF models for each instream habitat response variable in each region: one model using all candidate predictor variables, one using natural variables only (catchment area and slope) and one using anthropogenic (LUC) variables only. We compared pseudo- $r^{2}$ values for the three models and the RI values for individual variables to provide insights into the relative influence of anthropogenic and natural predictors, and their interactions, on instream habitat variables. All analyses were performed in R software (R Core Team 2013).

\section{Results}

Variation in landscape characteristics of stream sites

The first two PCA axes accounted for $65 \%$ (STM) and $57 \%$ (PGM) of the variation in landscape predictors of stream site conditions (Fig. 3; Tables S1, S2). Stream sites were widely distributed across the two main PCA axes. In STM, PCA1 broadly represented a gradient from areas with more intensive agriculture and historical land use (lower scores) to areas of high catchment and network riparian forest cover (higher scores); in PCA2, streams sites were distributed considering local riparian forest cover (lower scores) and number of road crossing (higher scores). In PGM,
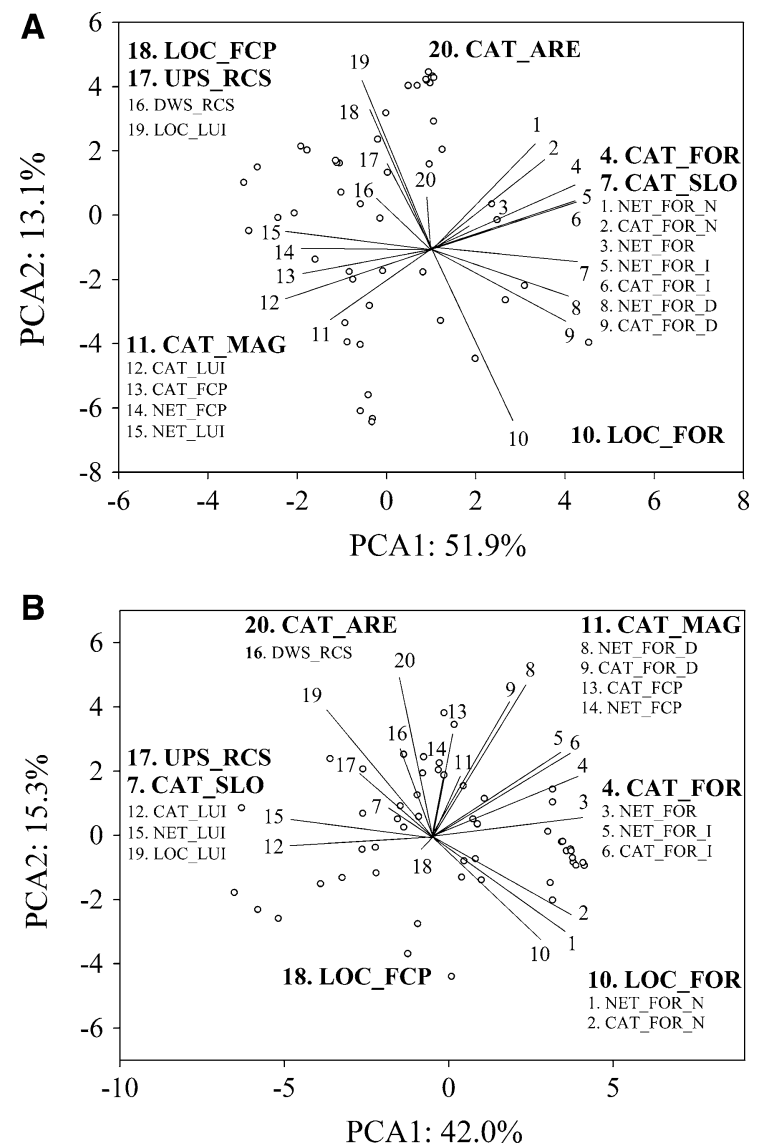

Fig. 3 Contribution of landscape predictor variables to the first two PCA axes for Santarém (a) and Paragominas (b) stream sites (circles). Variables in bold were selected for further analysis, with excluded highly correlated metrics listed below each of them 
forest cover had a positive influence on PCA1 and negative influence on PCA2, and anthropogenic indicators were negatively correlated with PCA1 and positively with PCA2.

For both regions, high correlations $\left(r_{\text {Pearson }}>0.7\right)$ among predictor variables and PCAs were mainly consistent, allowing the selection of the same set of relatively uncorrelated variables. Correlations were particularly high between catchment and network riparian scale variables, for instance $r_{\text {Pearson }}$ between catchment forest (CAT_FOR) and network riparian forest (NET_FOR) was 0.91 for STM and 0.83 for PGM (Table S3 and S4). Because of these high correlations among scales, we decided to focus on the catchment scale because this subsumes the network riparian zone and provides a broader representation of the landscape.

The subset of variables with low correlations with other predictor variables in both regions (Fig. S2) were catchment slope (CAT_SLO) and catchment area (CAT_ARE) (natural predictors); and percentage of catchment forest (CAT_FOR), percentage of local riparian forest (LOC_FOR), local FCCP (LOC_FCP), catchment mechanized agriculture (CAT_MAG) and number of upstream road crossings (UPS_RCS) (anthropogenic predictors). Those seven variables were used as predictors of the variability in the instream habitat response variables.

\section{LUC influences on stream site condition}

Random forest models explained some of the observed variance (1.7-49.2 \% in STM and 2.1-34.7 in PGM) in 14 out of the 25 instream habitat variables in each region when all landscape predictors, anthropogenic and natural, were included in the models (Tables 3, S5). In general, the inclusion of all predictor variables resulted in better model fits than when only natural or only anthropogenic were included, indicating that LUC effects can depend on differences in the natural characteristics of a given region. The anthropogenic variables alone accounted for $0.8-27.6 \%$ of the variance in the instream habitat responses for STM and $1.1-34.7 \%$ for PGM. Response variables that were partly explained by LUC characteristics in each region included variables from all major instream habitat categories: water quality, substrate, cover and wood, channel morphology, and other (e.g., discharge, channel shading).
Variability in ten instream habitat variables was partly explained in both regions: temperature (TEMP), conductivity (COND), wood (WOOD), bankfull width-to-depth ratio (BKWD), standard deviation of thalweg depth (DPTH), wetted width $\times$ thalweg depth (WDDP), residual depth at thalweg (RP100), discharge (DSCH), critical diameter of substrate (LDMB), and mid-channel shading (SHAD) (Table 3). Among those, five had the same major predictor in both regions: local riparian forest cover for SHAD, WOOD and LDMB, road crossings for COND, and local FCCP for DSCH (Table S5).

The degree to which the predictor variables explained the instream habitat measures differed between regions. For STM, seven response variables had more than $10 \%$ of their variation explained by anthropogenic predictors: discharge $(27.6 \%)$, standard deviation of thalweg depth $(17.0 \%)$, residual depth at thalweg $(14.7 \%)$, wetted width $\times$ thalweg depth $(14.6 \%)$, slope $(13.1 \%)$, wood $(12.5 \%)$, and mid-channel shading (11.0\%) (Table 3). For PGM, temperature $(34.7 \%)$, mid-channel shading $(33.7 \%)$, and bankfull width-to-depth ratio $(12.5 \%)$ were the instream habitat response variables best explained by the anthropogenic predictors.

Influence of region and landscape scale on instream habitat condition

In both regions, variation in instream habitat response variables was driven by many predictors, with each explaining small amounts (Fig. 4). In PGM, forest cover-related predictors were more important than other variables in explaining variability in instream habitat. Road crossings (UPS_RCS) in STM appeared to be the most important influence on many instream habitat response variables. Mechanized agriculture (CAT_MAG) was retained in most of the predictive models for STM, but in PGM, only one instream habitat response variable was explained by CAT_MAG.

Partial contributions of single predictors were smaller in STM than in PGM. Local riparian forest cover (LOC_FOR) was positively related to wood and accounted for $11 \%$ of observed variance, with a marked increase in the volume of wood observed when forest cover exceeded $80 \%$ (Fig. 5a). FCCP (LOC_FCP) was associated with $9.5 \%$ of the variation in discharge, without a clear directional relationship (Fig. 5b). Road crossings (UPS_RCS) were 
Table 3 Performance of random forest (RF) models showing the percentage of variation of the instream habitat response variables explained (pseudo- $\mathrm{R}^{2}$ ) by models that included all predictor variables (All), only the anthropogenic (Ant) and only the natural variables $(\mathrm{Nat})^{\mathrm{a}}$

\begin{tabular}{|c|c|c|c|c|c|c|c|}
\hline \multirow{2}{*}{\multicolumn{2}{|c|}{ Instream habitat }} & \multicolumn{3}{|c|}{ STM } & \multicolumn{3}{|c|}{ PGM } \\
\hline & & All (\% Ant) & Ant & Nat & All (\% Ant) & Ant & Nat \\
\hline \multirow{3}{*}{ Water } & TEMP & $5.5(100)$ & 5.3 & 0 & $34.7(100)$ & 35.2 & 0 \\
\hline & DO & $1.7(88)$ & 7.7 & 0 & 0 & 0 & 0 \\
\hline & COND & $2.3(35)$ & 0 & 0 & $6.8(28)$ & 0 & 16.23 \\
\hline \multirow{4}{*}{ Substrate } & FINE & 0 & 0 & 9.3 & $6.6(53)$ & 3.4 & 0.7 \\
\hline & SAFN & 0 & 0 & 0 & $13.5(44)$ & 6 & 3.6 \\
\hline & FNGR & $6.6(55)$ & 1.7 & 6.9 & 0 & 0 & 0 \\
\hline & $\mathrm{D}_{\mathrm{gm}}$ & $14.6(55)$ & 8.2 & 2.8 & 0 & 0 & 0 \\
\hline $\begin{array}{c}\text { Cover and } \\
\text { wood }\end{array}$ & WOOD & $12.5(100)$ & 9.5 & 0 & $11.7(62)$ & 1.7 & 0 \\
\hline \multirow{8}{*}{$\begin{array}{l}\text { Channel } \\
\text { morphology }\end{array}$} & WDDP & $31(47)$ & 17.0 & 9.6 & $3.2(50)$ & 0 & 0 \\
\hline & DPTH & $28.6(59)$ & 18.9 & 12.4 & $9.7(30)$ & 0 & 0 \\
\hline & BKAN & 0 & 0 & 0 & $6.7(75)$ & 0 & 3.9 \\
\hline & BKWD & $5.1(78)$ & 2.0 & 0 & $27.9(45)$ & 3.1 & 0 \\
\hline & RP100 & $37.2(40)$ & 16.5 & 44.6 & $2.1(52)$ & 0 & 8.2 \\
\hline & SLOP & $35.8(37)$ & 12.4 & 40.0 & 0 & 0 & 0 \\
\hline & FAST & 0 & 0 & 1.9 & $8.1(96)$ & 12.3 & 0 \\
\hline & DSCH & $49.2(56)$ & 33.1 & 40.2 & $3.8(87)$ & 8.7 & 0 \\
\hline \multirow[t]{2}{*}{ Other } & LDMB & $9.2(67)$ & 14.4 & 0 & $2.8(28)$ & 3.1 & 0.1 \\
\hline & SHAD & $18.8(59)$ & 25.8 & 0 & $33.7(100)$ & 34.3 & 0 \\
\hline
\end{tabular}

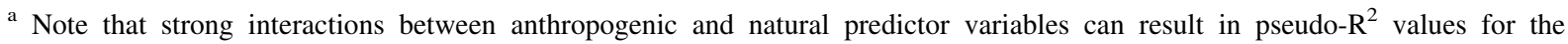
combined (All) model that exceed the sum of values for anthropogenic and natural models (e.g. $\mathrm{D}_{\text {gm }}$ in STM; highlighted in light grey). Conversely, the combined model can have lower pseudo- $\mathrm{R}^{2}$ values than anthropogenic (medium grey) or natural (dark grey) models because the random inclusion of weaker predictors in individual trees may lower the overall mean predictive performance (e.g. DO in STM and COND in PGM respectively). Values in parentheses in "All" columns show the \% contribution of anthropogenic variables to total variance explained in combined models 
Fig. 4 Representation of random forest $(\mathrm{RF})$ models showing the percentage of variation of the instream habitat response variables explained (pseudo- $\mathrm{R}^{2}$ ) by anthropogenic predictor variables in Amazonian stream sites. Results are from models that included both anthropogenic and natural predictor variables ('All' models shown on Table 3)

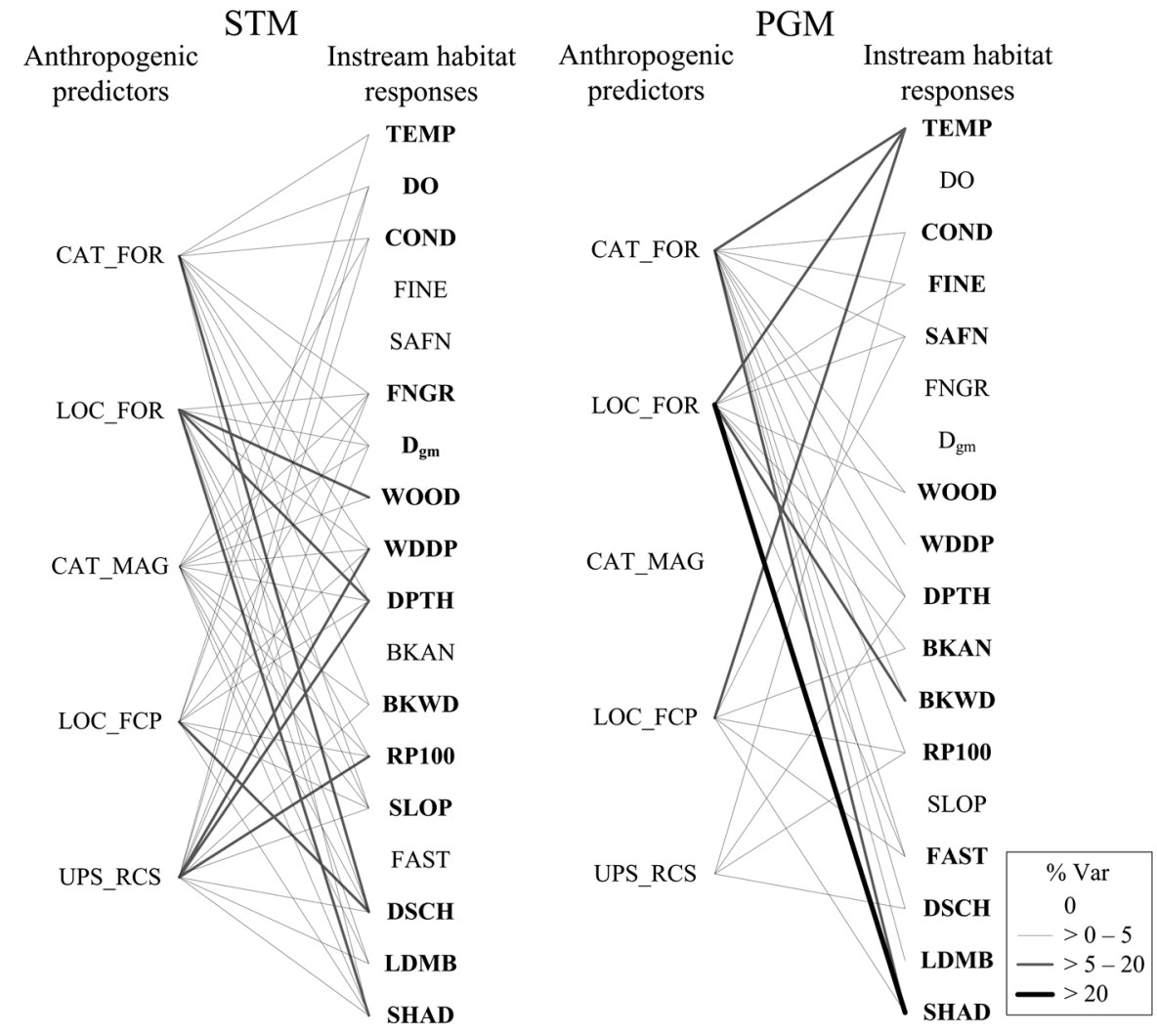

negatively related to wetted width $\times$ thalweg depth (WDDP), an indicator of wetted channel volume, and explained $10.8 \%$ of its variance (Fig. $5 \mathrm{c}$ ).

For PGM, local forest accounted for $20.2 \%$ of the variance in mid-channel shading, showing a consistent positive relationship (Fig. 5d). Forest cover at the catchment scale had a negative relationship with temperature, explaining $20.0 \%$ of the observed variance (Fig. 5e). The partial plots suggest there is a threshold at ca. $80 \%$ of catchment forest cover above which water temperature is consistently cooler than in more deforested areas. For bankfull width-to-depth ratio (BKWD), local riparian forest cover was the most important predictor, explaining $10.6 \%$ of its variance (Fig. 5f), with wider or shallower channels associated with stream sites having deforested adjacent areas.

\section{Discussion}

Our study is the first comprehensive, quantitative, multi-scale assessment of the consequences of LUC on water quality and physical habitat of small Amazonian streams. Drawing on detailed landscape and habitat data we confirm the importance of linkages between human activities and some key instream habitat response variables, including water temperature, discharge, and the volume of dead wood. Importantly, we also found evidence of threshold effects relating to upstream deforestation. However, our data also highlighted the heterogeneous nature of such stream systems and the difficulties of identifying specific predictor variables; i.e., most habitat response variables were affected by several to many correlated predictor variables that differed between regions. We discuss our findings by comparing them with a priori expectations while also assessing some of the challenges involved in understanding the links between anthropogenic disturbances and the instream habitat of tropical streams. We draw on the relationships observed in our data to suggest priorities for the management of land and stream systems in humanmodified tropical forest landscapes in general, and in Brazil in particular. 


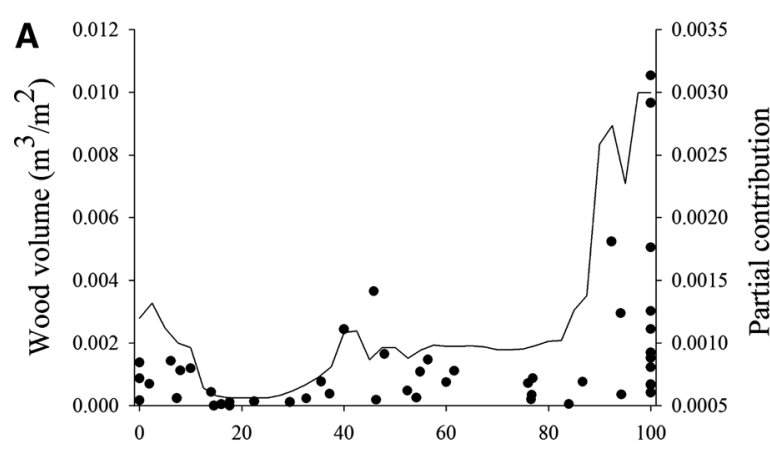

Percentage of local riparian forest (LOC_FOR)

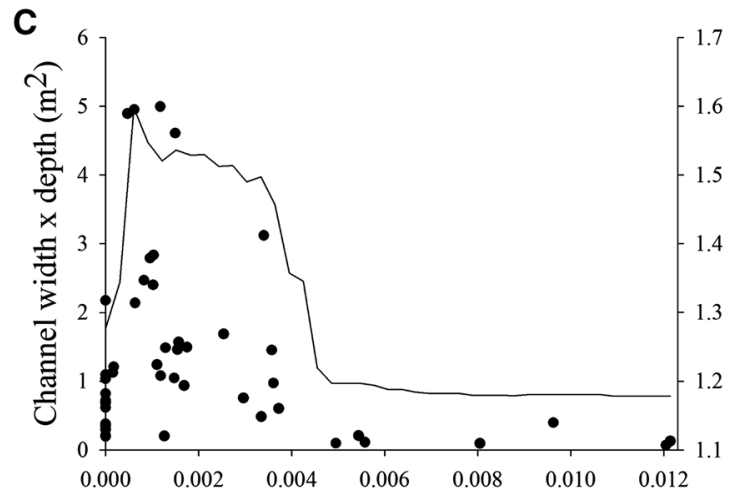

Number of upstream road crossings $/ \mathrm{km}^{2}$ (UPS_RCS)

\section{E}

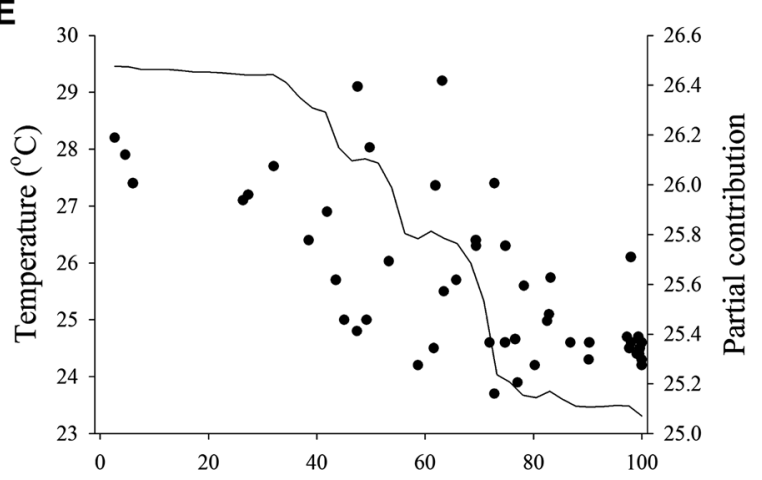

Percentage of catchment forest (CAT_FOR)

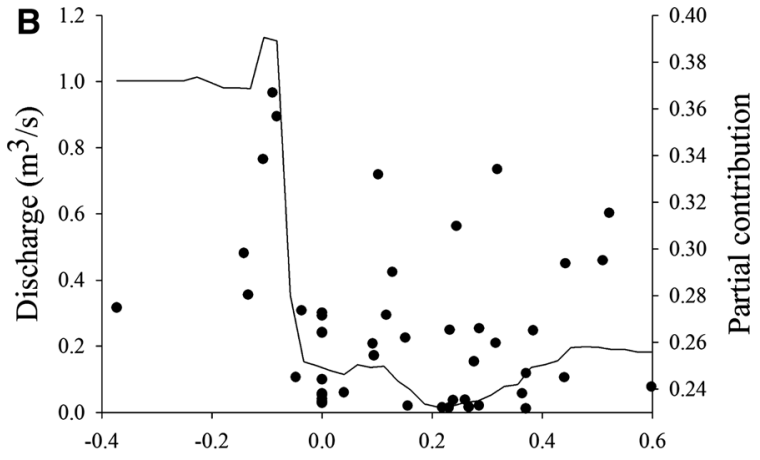

Local forest change curvature profile (LOC_FCP)

D

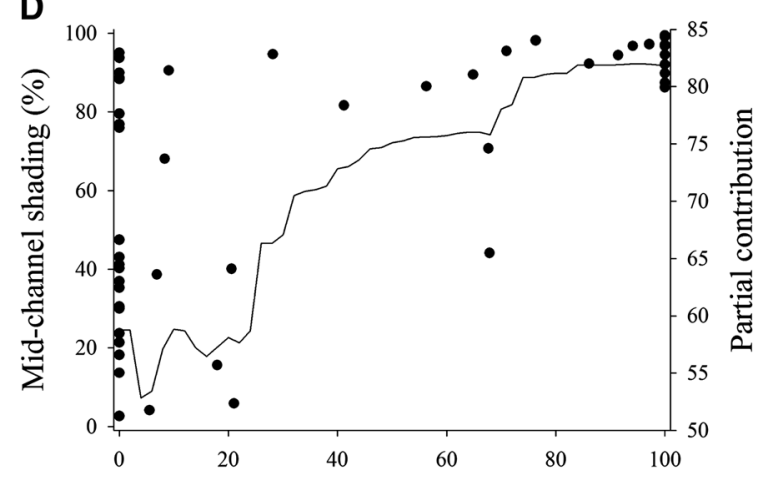

Local forest change curvature profile (LOC_FCP)

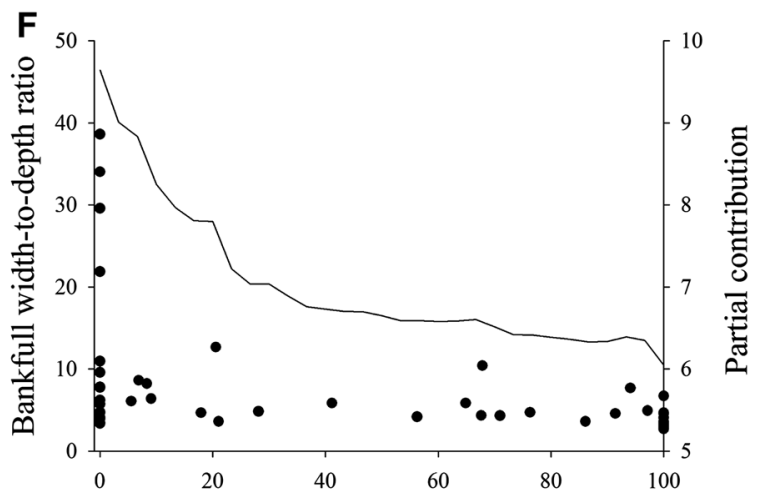

Local forest change curvature profile (LOC FCP)

Fig. 5 Raw data distribution (dots) and partial contribution of landscape predictor variables (lines) to instream habitat in Santarém (a, b, c) and Paragominas $(\mathbf{d}, \mathbf{e}, \mathbf{f})$

Do human-induced disturbances influence tropical instream habitats?

The importance of landscape change in altering instream habitats has been the focus of far more research in temperate than tropical streams (Allan 2004; Hughes et al. 2006; Beschta et al. 2013; Yeakley et al. 2014). In our assessment of small Amazonian streams, we found evidence that human-induced landscape disturbances were associated with noticeable changes in several important aspects of instream habitat (Fig. 4; Table 3). The strongest of these effects links the warming of streams with upstream deforestation, which is consistent with other studies 
showing increases in water temperature in response to deforestation (Figueiredo et al. 2010; Macedo et al. 2013). Notably, results from PGM indicate a clear threshold, where streams with $<80 \%$ upstream forest cover had higher water temperatures. This is important, as temperature increases in temperate streams are known to affect the composition and life-histories of aquatic species (Gillooly et al. 2001, 2002; Lorion and Kennedy 2008, 2009; Isaak et al. 2011; Neuheimer et al. 2011).

Local riparian forest cover was important for determining the volume of wood, which is a critical factor influencing long-term channel structural complexity (e.g. by forming pools and cascades), substrate composition for faunal colonization, and sediment and leaf litter accumulation (Wright and Flecker 2004; Milner and Gloyne-Phillips 2005; Kaufmann and Faustini 2012). Although a positive link between forest cover and wood input is not surprising, the influence of catchment level drivers in STM highlights that these effects span multiple scales. These results reflect those of Paula et al. (2013), who found that local riparian forests were important sources of instream wood in tropical streams, but also noted the importance of forests along the upstream network riparian zone and the entire upstream catchment because of downstream transport of wood. In addition, our data suggest that a number of other factors are associated with this habitat feature, including mechanized agriculture in STM and road crossings in PGM.

Challenges to understanding the influences of anthropogenic disturbances on instream habitat in tropical streams

\section{Linking observed relationships with landscape history}

One of the more surprising aspects of our study was that the effects of LUC on instream habitat are not always consistent across regions. For example, some changes in instream habitat that were clearly evident in one region were not in the other (e.g. response of temperature to forest cover, and LUC effects on stream substrate size and percentage of fine gravel). These differences emphasize the complexity of understanding relationships between LUC and instream habitat, and show the variability in responses for regions that have different land-use histories and hence environmental legacies (Allan et al. 1997;
Uriarte et al. 2011). STM has an older history of colonization that started ca. 350 years ago whereas LUC in PGM is more recent, since ca. 60 years ago. Yet both regions are similarly consolidated regarding the current mosaic of land uses and have experienced similar recent histories of LUC. The observed differences in instream habitat responses are presumably related to a combination of biophysical and anthropogenic differences between regions, also noting that instream habitat characteristics can exhibit delayed responses to LUC.

Idiosyncrasies in the instream habitat responses highlight the difficulty of any a priori process to select candidate variables to describe both landscape drivers and instream habitat responses to disturbance, and hence the need to survey a wide range of measures. This is particularly important regarding future research in other poorly studied regions, as it is challenging to decide both the specific habitat variables and scales of measurement that may be most relevant.

\section{Disentangling the effects of anthropogenic disturbance from natural variation among Amazonian streams}

The high level of multi-collinearity between natural stream characteristics and anthropogenic disturbance hinders efforts to disentangle the relative importance of individual factors in determining changes in the physical and chemical attributes of streams (Allan et al. 1997; Allan 2004). Moreover LUC effects on stream condition are scale-dependent with different drivers influencing specific aspects of stream condition at distinct spatial and temporal scales (Allan et al. 1997; Gergel et al. 2002; Uriarte et al. 2011). We found that Amazonian streams are highly heterogeneous in their natural physical habitat and water quality characteristics, hampering our ability to detect the effects of specific disturbances. This is especially the case regarding stream sediment characteristics, which are strongly influenced by both natural landscape features and the loss of native vegetation. The percent of sand and fine sediments at stream sites varied substantially within both completely forested and largely deforested ( $<10 \%$ forest cover) catchments in both regions. This may have resulted from at least three factors: (1) our definition of forest, as primary forests and second-growth forests that are 
over 10 years in age may be too broad; (2) the fact that LUC itself is not a random process, and forests on sandy soils are largely avoided for agriculture; and (3) both regions are underlain by paleo-lake bed sediments with high levels of sand and fine sediments. In Santarém, stream sites draining forested catchments had $31-40 \%$ of sand and fine sediments compared to 10-31\% for deforested catchments. However in PGM, the variation was greater for forested catchments (22-63\%) and bounded the range observed in deforested catchments (36-47\%).

\section{The importance of catchment scale management}

It is well established that the loss of riparian vegetation can be detrimental to several stream characteristics and processes, such as sediment filtration, bank and flow stability, and channel shading with resultant changes in temperature and primary production regulation (Karr and Schlosser 1978; Peterjohn and Correll 1984; Osborne and Koviacic 1993; Sweeney 1993; Nerbonne and Vondracek 2001; Wang et al. 2006b; Sály et al. 2011; Macedo et al. 2014). However the common focus on management priorities within the riparian zone usually implies that the rest of the catchment is completely ignored (Allan et al. 1997). We demonstrate that upstream deforestation can also be associated with significant changes in downstream instream habitat, underscoring the need to move beyond the riparian zone and adopt a catchment-wide approach to managing these environments.

Our findings also highlight the role of drivers of instream habitat that are only linked indirectly to forest cover, such as the expansion of mechanized agriculture and number of road crossings, yet are crucially important for conserving and managing Amazonian stream systems. Both accounted for an important part of the instream habitat change, therefore are additional relevant considerations for conserving and managing Amazon stream systems. Agricultural mechanization can result in soil compaction, especially of the sedimentary soil types predominant in STM and PGM, leading to reduced rainfall infiltration, accelerated transport of water and fine sediment to streams, and changes in stream flow (Satterlund 1972; Allan 2004). Subsequent cascading effects can drive changes in several aspects of the physical habitat of streams, for instance stream size, habitat volume, streambed particle size and stability. Road crossings on small streams for private access and water use are considered as low environmental impacts by the Brazilian Environmental Council (CONAMA 2006; resolution \#369) in contrast to our results and those of others (Macedo et al. 2013; Neill et al. 2013). In our study, roads often crossed streams using undersized and perched culverts, creating small reservoirs upstream of the road. We found small dams built to provide water for cattle, small-scale fish production, and local hydroelectric power generation, all of which are commonly overlooked as serious disturbances to habitat and biota (Castello et al. 2013; Macedo et al. 2013; Neill et al. 2013). Macedo et al. (2013) estimated 10,000 small impoundments only in the Upper Xingu Basin in the lower Amazon, which together with deforestation accounted for $43 \%$ of the variation in stream temperature.

\section{Accounting for the full gradient of landscape disturbance}

While both of our study regions are characterized by a complex mosaic of land uses and forest cover, they still have a relatively high level of total forest cover (69 \% in PGM and $60 \%$ in Santarém). Moreover we sampled few heavily deforested catchments (only two catchments with $<10 \%$ forest cover in STM and three in PGM) and none of the study catchments were dominated by urban areas. Given that severely degraded streams were absent in the catchments we surveyed, environmental regulations may have helped to avoid the most extreme degradation from occurring (e.g. total removal of network riparian vegetation). We found that instream habitat variables commonly exhibited non-linear responses to disturbance and that the threshold for change in some variables occurred only at high levels of disturbance. This especially appeared to be the case for variables that exhibited similar response between the two regions yet had a weak response to disturbance (e.g. water conductivity in response to road crossings and critical diameter of stream substrate in response to changes in local riparian forest cover). Biggs et al. (2004) reported changes in nutrient levels only when deforestation was higher than $66 \%$, while Casatti et al. (2006a, b) found a greater decline in physical habitat quality than in water quality in degraded streams. 


\section{Time-lags in disturbance responses}

The ecological consequences of anthropogenic disturbances may take years to become fully apparent in ecosystems (Gibson et al. 2013; Hylander and Ehrlén 2013). Our results indicate that the historical deforestation pattern was an important predictor of instream habitat change in streams, as indicated by the importance of the local deforestation curvature profile index, LOC_FCP, in explaining the responses of several habitat variables (Table S5). Many of the more severe land use changes in both regions are relatively recent, the effects of which may not yet be manifested. PGM was founded in 1965 but timber extraction intensified only in the 1980s (Verissimo et al. 1992), whereas mechanized agriculture only grew significantly in the last ten years. Despite being founded in 1754 , Santarém has experienced a rapid increase in human population and rates of forest conversion only since the 1970s (Amorim 1999), with mechanized agriculture becoming relatively widespread only in the 2000s.

Some stream habitat and ecosystem metabolism features are known to exhibit much slower responses to disturbance than others (McTammany et al. 2007; Uriarte et al. 2011). It is interesting that we found strong relationships for water temperature, which we can expect to increase rapidly as a result of the clearance of riparian vegetation, while anthropogenic predictor variables explained $<10 \%$ of the variability in all substrate and wood variables-instream features that are likely to respond much more slowly to disturbance (e.g. Burnett et al. 2006). The lag time of woody material may be especially long in the tropics, where many trees have very high wood densities and very slow rates of decomposition. Such time lags in stream physical habitat responses may explain why historical land use of temperate catchments may account for more biological variability than current land use (Harding et al. 1998; Brown et al. 2009).

Implications for the conservation of Amazonian streams

In recent years, there has been a decrease in annual deforestation in the Brazilian Amazon associated with, among other factors, several initiatives led by the government with support from non-government organizations (NGOs) and the private sector. Those initiatives include increased law enforcement and punitive actions, increases in the protected areas network, and moratoria on the production of soy and beef from recently deforested areas (Boucher et al. 2013; Nepstad et al. 2014). Despite these positive changes, management strategies have largely failed to address the environmental damage caused by deforestation and LUC on the hydrological connectivity of streams (Castello et al. 2013). Our results highlight some of the inadequacies of current Brazilian legislation in protecting stream environments in particular and point to ways in which their management and conservation could be improved. Two Brazilian legal instruments directly concerned with instream habitats are the Fisheries Code (Federal Law No 11.959, June 29th 2009; Brasil 2009) and the Water Resources Regulation (Federal Law No 9.433, January 8th 1997; Brasil 1997). The first focuses on aquaculture and fishing activities, and the second on water quality variables considered important to human consumption. However, both only permit a narrow legal perspective of stream condition and mask the importance of other degradation processes resulting in potentially misleading conclusions about the biotic integrity of stream systems (Karr and Dudley 1981; Casatti et al. 2006a, b; Paulsen et al. 2008).

The most important piece of legislation regarding the protection of the broader stream environment, including adjacent native vegetation, is the Forest Code (Federal Law No 12.651, May 25th 2012; Brasil 2012) that prescribes the majority of environmental regulations for private properties that cover $50 \%$ of the country's native vegetation (Soares-Filho et al. 2014). The Forest Code stipulates that $80 \%$ of the native vegetation in properties in the Amazon (reduced to $50 \%$ in areas that have been zoned for agricultural activities) should be protected in Legal Reserves, with an obligation to restore the forest area to $50 \%$ for areas that were illegally cleared prior to 2008. The law requires that, depending on the property size, a minimum buffer of riparian vegetation must be protected alongside all water courses, although the revised Forest Code reduced the riparian vegetation buffer width that is mandated to be restored to $5 \mathrm{~m}$ for areas that have been declared for agricultural use. Our results highlight two important limitations in the effectiveness of this legislation to conserve stream environments. First, we have identified the importance of upstream forests - and not just riparian forests-in determining local stream habitat conditions, 
demanding a more collective-action (versus individual) approach to achieving compliance across neighbouring landowners to protect blocks of forest in individual catchments. Second, the influence of upand down-stream habitat fragmentation from road crossings and from mechanized agriculture on instream physical environments emphasizes the need for legislation to go beyond protecting only riparian forests and contribute towards mitigating against the effects of multiple disturbances throughout entire drainage networks (Allan et al. 1997; Abell et al. 2007; Castello et al. 2013). Our findings highlight the urgent need for greater attention to be given to the conservation and management of small-streams in other tropical landscapes, which are under increasing pressure due to agricultural expansion and intensification (DeFries and Rosenzweig 2010). In particular we underscore the need to consider impacts from LUC across entire catchments, and not just in areas of riparian forest, as well as the importance of anthropogenic disturbances not directly related to deforestation, such as changes in agricultural intensification and disruption to the connectivity of stream systems from road crossings and other disturbances.

Acknowledgments We dedicate this paper to Manoel Nascimento (aka "Nego") for his invaluable work as a field technician and naturalist. We thank Ceceo Chaves, Débora de Carvalho, Douglas Bastos, Elbin da Silva, Francisco Cunha ("Pita"), Janaína de Brito, José Max de Oliveira-Silva, Karina Silva, Leandro Brasil, Leandro Juen, Lenise Flores, Lucas Pires, Marcos Vinícius da Silva, Martinez de Oliveira, Míriam de Almeida, Rafael Duarte, Renilson de Freitas ("Graveto"), Túlio Franco, Valderir Nascimento, and Vivian de Oliveira for their assistance in the field work and the farmers and workers unions of Santarém, Belterra, and Paragominas and all collaborating private landowners for their support. We are also grateful for financial support from Instituto Nacional de Ciência e Tecnologia-Biodiversidade e Uso da Terra na Amazônia (CNPq; 574008/2008-0), Empresa Brasileira de Pesquisa Agropecuária (Embrapa; SEG: 02.08.06.005.00), the UK government Darwin Initiative (17-023), The Nature Conservancy, Natural Environment Research Council (NERC; NE/F01614X/1 and NE/G000816/1), and Fulbright Brasil. Individual funding included a Coordenação de Aperfeiçoamento de Pessoal de Nível Superiror (CAPES) scholarship in Brazil and a Science without Borders Grant in the United Kingdom (PDSE-2943/13-1) to CGL; a CNPq (304002/2014-3) and a FAPEMIG (PPM-00608/15) research fellowship to PSP; CNPq (\#156915/2011-1) and CAPES Science Without Borders Grant in France (PDSE-1914/13-8) to RPL, and a CNPq Award (400640/2012-0) to JB. Our manuscript benefitted greatly from reviews by Dr. Péter Sály, Dr. Ryan Hill, and two anonymous reviewers. It was subjected to review by the U.S. Environmental Protection Agency
National Health and Environmental Effects Research Laboratory's Western Ecology Division and approved for publication. Approval does not signify that the contents reflect the views of the Agency, nor does mention of trade names or commercial products constitute endorsement or recommendation for use. This paper is \#47 in the Sustainable Amazon Network (http://www.redeamazoniasustentavel.org/) and \#43 in Projeto Igarapés (http://www.igarapes.bio.br) publication series.

\section{Compliance with ethical standards}

Conflict of interest The authors declare that they have no conflict of interest.

Open Access This article is distributed under the terms of the Creative Commons Attribution 4.0 International License (http:// creativecommons.org/licenses/by/4.0/), which permits unrestricted use, distribution, and reproduction in any medium, provided you give appropriate credit to the original author(s) and the source, provide a link to the Creative Commons license, and indicate if changes were made.

\section{References}

Abell R, Allan J, Lehner B (2007) Unlocking the potential of protected areas for freshwaters. Biol Conserv 134:48-63

Acker JG, Leptoukh G (2007) Online analysis enhances use of NASA Earth science data. EOS Trans Am Geophys Union $88: 14$

Allan JD (2004) Landscapes and riverscapes: the influence of land use on stream ecosystems. Annu Rev Ecol Evol Syst 35:257-284

Allan JD, Erickson DL, Fay J (1997) The influence of catchment land use on stream integrity across multiple spatial scales. Freshw Biol 37:149-161

Amorim A (1999) Santarém: uma síntese histórica. ULBRA, Canoas

Asner GP, Knapp DE, Broadbent EN, Oliveira PJC, Keller M, Silva JN (2005) Selective logging in the Brazilian Amazon. Science 310:480-482

Beschta RL, Donahue DL, Dellasala DA, Rhodes JJ, Karr JR, O'Brien MH, Fleischner TL, Williams CD (2013) Adapting to climate change on western public lands: addressing the ecological effects of domestic, wild, and feral ungulates. Environ Manag 51:474-491

Biggs TW, Dunne T, Martinelli LA (2004) Natural controls and human impacts on stream nutrient concentrations in a deforested region of the Brazilian Amazon basin. Biogeochemistry 68:227-257

Boucher D, Roquemore S, Fitzhugh E (2013) Brazil's success in reducing deforestation. Trop Conserv Sci 6:426-445

Boulton AJ, Boyero L, Covich AP, Dobson M, Lake S, Pearson R (2008) Are tropical streams ecologically different from temperate streams? In: Dudgeon D (ed) Tropical stream ecology. Elsevier, London, pp 257-284

Boyero L, Ramírez A, Dudgeon D, Pearson RG (2009) Are tropical streams really different? J N Am Benthol Soc 28:397-403 
Brasil (1997) Lei No 9.433 de 8 de janeiro de 1997. http://www. planalto.gov.br/ccivil_03/leis/19433.htm. Accessed Feb 2014

Brasil (2009) Lei No 11.959 de 29 de junho de 2009. http:// www.planalto.gov.br/ccivil_03/_ato2007-2010/2009/Lei/ L11959.htm. Accessed Feb 2014

Brasil (2012) Lei No 12.651 de 12 de maio de 2012. http://www. planalto.gov.br/ccivil_03/_ato2011-2014/2012/lei/112651. htm. Accessed Jan 2014

Brauman KA, Daily GC, Duarte TK, Mooney HA (2007) The nature and value of ecosystem services: an overview highlighting hydrologic services. Annu Rev Environ Resour 32:67-98

Breiman L (2001) Random forests. Mach Learn 45:5-32

Brown LR, Cuffney TF, Coles JF, Fitzpatrick F, McMahon G, Steuer J, Bell AH, May JT (2009) Urban streams across the USA: lessons learned from studies in 9 metropolitan areas. J N Am Benthol Soc 28:1051-1069

Burnett KM, Reeves GH, Clarke SE, Christiansen KR (2006) Comparing riparian and catchment influences on stream habitat in a forested, montane landscape. In: Hughes RM, Wang L, Seelbach PW (eds) Landscape influences on stream habitats and biological assemblages. American Fisheries Society Symposium 48, Bethesda, pp 175197

Butchart SHM, Walpole M, Collen B, van Strien A, Scharlemann JPW, Almond REA, Baillie JEM, Bomhard B, Brown C, Bruno J, Carpenter KE, Carr GM, Chanson J, Chenery AM, Csirke J, Davidson NC, Dentener F, Foster M, Galli A, Galloway JN, Genovesi P, Gregory RD, Hockings M, Kapos V, Lamarque JF, Leverington F, Loh J, McGeoch MA, McRae L, Minasyan A, Morcillo MH, Oldfield TEE, Pauly D, Quader S, Revenga C, Sauer JR, Skolnik B, Spear D, Stanwell-Smith D, Stuart SN, Symes A, Tierney M, Tyrrell TD, Vié JC, Watson R (2010) Global biodiversity: indicators of recent declines. Science 328:1164-1168

Casatti L, Langeani F, Ferreira CP (2006a) Effects of physical habitat degradation on the stream fish assemblage structure in a pasture region. Environ Manag 38:974-982

Casatti L, Langeani F, Silva AM, Castro RMC (2006b) Stream fish, water and habitat quality in a pasture dominated basin, southeastern Brazil. Braz J Biol 66:681-696

Castello L, McGrath DG, Hess LL, Coe MT, Lefebvre PA, Petry P, Macedo MN, Renó VF, Arantes CC (2013) The vulnerability of Amazon freshwater ecosystems. Conserv Lett 6:217-229

CONAMA (2006) Resolução CONAMA no 369, de 28 de março de 2006. http://www.mma.gov.br/port/conama/ legiabre.cfm?codlegi=489. Accessed April 2014

Davidson EA, Neill C, Krusche AV, Ballester VVR, Markewitz D, Figueiredo RO (2004) Loss of nutrients from terrestrial ecosystems to streams and the atmosphere following land use change in Amazonia. In: DeFries RS, Asner GP, Houghton RA (eds) Ecosystem land use change. American Geophysical Union, Washington, D. C., pp 147-158

Davidson EA, de Araújo AC, Artaxo P, Balch JK, Brown IF, Bustamante MMC, Coe MT, DeFries RS, Keller M, Longo M, Munger JW, Schroeder W, Soares-Filho BS, Souza CM, Wofsy SC (2012) The Amazon basin in transition. Nature 481:321-328 de Paula FR, Gerhard P, Wenger SJ, Ferreira A, Vettorazzi CA, Ferraz SFB (2013) Influence of forest cover on in-stream large wood in an agricultural landscape of southeastern Brazil: a multi-scale analysis. Landscape Ecol 28:13-27

DeFries R, Rosenzweig C (2010) Toward a whole-landscape approach for sustainable land use in the tropics. Proc Natl Acad Sci USA 107:19627-19632

Di Luzio M, Srinivasan R, Arnold JG (2004) A GIS-coupled hydrological model system for the watershed assessment of agricultural nonpoint and point sources of pollution. Trans GIS 8:113-136

Dudgeon D (2008) Tropical stream ecology. Elsevier, London

Ellis EC (2011) Anthropogenic transformation of the terrestrial biosphere. Philos Trans R Soc A 369:1010-1035

Ellis N, Smith SJ, Roland Pitcher C (2012) Gradient forests: calculating importance gradients on physical predictors. Ecology 93:156-168

Embrapa (2006) Sistema brasileiro de classificação de solos, 2nd edn. Embrapa, Rio de Janeiro

Fearnside PM, Pueyo S (2012) Greenhouse-gas emissions from tropical dams. Nat Clim Chang 2:382-384

Ferraz SFB, Begotti RA, Cassiano CC, Ferraz KMPMB, Pinto TA (2011) Assessing dynamic landscapes by forest change curvature profile (FCCP). In: 26th annual landscape ecology symposium. Sustainability in dynamic landscapes

Ferraz SFB, Cassiano CC, Begotti RA, Tranquilin AR (2012) Land use change analysis tools (LUCAT). II Congr. Bras. Ecol, Paisagens

Ferraz SFB, Ferraz KMPMB, Cassiano CC, Brancalion PHS, Luz DTA, Azevedo TN, Tambosi LR, Metzger JP (2014) How good are tropical forest patches for ecosystem services provisioning? Landscape Ecol 29:187-200

Ferraz SFDB, Vettorazzi CA, Theobald DM (2009) Using indicators of deforestation and land-use dynamics to support conservation strategies: a case study of central Rondônia, Brazil. For Ecol Manag 257:1586-1595

Ferreira J, Aragão LEOC, Barlow J , Barreto P, Berenguer E, Bustamante M, Gardner TA, Lees AC, Lima A, Louzada J, Pardini R, Parry P, Peres CA, Pompeu PS, Tabarelli M, Zuanon J (2014) Brazil's environmental leadership at risk. Science 346:706-707

Figueiredo RO, Markewitz D, Davidson EA, Schuler AE, Watrin OS, Silva PS (2010) Land-use effects on the chemical attributes of low-order streams in the eastern Amazon. J Geophys Res 115:G04004

Foley JA, Defries R, Asner GP, Barford C, Bonan G, Carpenter SR, Chapin FS, Coe MT, Daily GC, Gibbs HK, Helkowski JH, Holloway T, Howard EA, Kucharik CJ, Monfreda C, Patz JA, Prentice IC, Ramankutty N, Snyder PK (2005) Global consequences of land use. Science 309:570-574

Gardner TA, Ferreira J, Barlow J, Lees A, Parry L, Vieira ICG, Berenguer E, Abramovay R, Aleixo A, Andretti C, Aragão LEOC, Araújo I, Ávila WS, Bardgett RD, Batistella M, Begotti RA, Beldini T, Blas DE, Braga RF, Braga DL, Brito JG, Camargo PB, Santos FC, Oliveira VC, Cordeiro ACN, Cardoso TM, Carvalho DR, Castelani SA, Chaul JCM, Cerri CE, Costa FA, Costa CDF, Coudel E, Coutinho AC, Cunha D, D'Antona A, Dezincourt J, Dias-Silva K, Durigan M, Esquerdo JCDM, Feres J, Ferraz SFB, Ferreira AEM, Fiorini AC, Silva LVF, Frazão FS, Garrett R, Gomes AS, Gonçalves KS, Guerrero JB, Hamada N, Hughes RM, 
Igliori DC, Jesus EC, Juen L, Junior M, Junior JMBO, Junior RCO, Junior CS, Kaufmann P, Korasaki V, Leal CG, Leitão RP, Lima N, Almeida MFL, Lourival R, Louzada J, Nally RM, Marchand S, Maués MM, Moreira FMS, Morsello C, Moura N, Nessimian J, Nunes S, Oliveira VHF, Pardini R, Pereira HC, Pompeu PS, Ribas CR, Rossetti F, Schmidt FA, Siva R, Silva RCVM, Silva TFMR, Silveira J, Siqueira JV, Carvalho TS, Solar RRC, Tancredi NSH, Thomson JR, Torres PC, Vaz-de-Mello FZ, Veiga RCS, Venturieri A, Viana C, Weinhold D, Zanetti R, Zuanon JAS (2013) A social and ecological assessment of tropical land uses at multiple scales : the sustainable Amazon Network. Philos Trans R Soc B 368:20120166

Gergel SE, Turner MG, Miller JR, Melack JM, Stanley EH (2002) Landscape indicators of human impacts to riverine systems. Aquat Sci 64:118-128

Gibson L, Lynam AJ, Bradshaw CJA, He F, Bickford DP, Woodruff DS, Bumrungsri S, Laurance WF (2013) Nearcomplete extinction of native small mammal fauna 25 years after forest fragmentation. Science 341(80):1508-1510. doi:10.1126/science. 1240495

Gillooly JF, Brown JH, West GB, Savage VM, Charnov EL (2001) Effects of size and temperature on metabolic rate. Science 293:2248-2251

Gillooly JF, Charnov EL, West GB, Savage VM, Brown JH (2002) Effects of size and temperature on developmental time. Nature 417:70-73

Gregory SV, Swanson FJ, Mckee WA, Cummins KW (1991) An ecosystem perspective of riparian zones: focus on links between land and water. Bioscience 41:540-551

Harding JS, Benfield EF, Bolstad PV, Helfman GS, Jones EBD (1998) Stream biodiversity: the ghost of land use past. Proc Natl Acad Sci USA 95:14843-14847

Hughes RM, Peck DV (2008) Acquiring data for large aquatic resource surveys: the art of compromise among science, logistics, and reality. J N Am Benthol Soc 27:837-859

Hughes RM, Wang L, Seelbach PW (2006) Landscape influences on stream habitats and biological assemblages. American Fisheries Society Symposium 48, Bethesda

Hylander K, Ehrlén J (2013) The mechanisms causing extinction debts. Trends Ecol Evol 28:341-346

Isaak DJ, Wollrab S, Horan D, Chandler G (2011) Climate change effects on stream and river temperatures across the northwest U.S. from 1980-2009 and implications for salmonid fishes. Clim Chang 113:499-524

Jarvis A, Reuter HI, Nelson A, Guevara E (2008) Hole-filled SRTM for the globe Version 4, available from the CGIARCSI SRTM 90m Database. http://srtm.csi.cgiar.org

Jensen JR (2000) Remote sensing of the environment: an earth resource perspective, 2nd edn. Prentice Hall, Cloth

Junk WJ (1983) Aquatic habitats in Amazonia. Environ Syst Decis 3:24-34

Junk WJ, Wantzen KM (2004) The flood pulse concept: new aspects, approaches and applications: an update. In: Proceedings of second international symposium on the management of large rivers fish, pp 117-149

Karr JR, Dudley DR (1981) Ecological perspective on water quality goals. Environ Manag 5:55-68

Karr JR, Schlosser IJ (1978) Water resources and the land-water interface. Science 201:229-234
Kaufmann PR, Faustini JM (2012) Simple measures of channel habitat complexity predict transient hydraulic storage in streams. Hydrobiologia 685:69-95

Kaufmann PR, Levine P, Robison EG, Seeliger C, Peck DV (1999) Quantifying physical habitat in wadeable streams. EPA/620/R-99/003. U.S. Environmental Protection Agency, Washington, D.C

Kaufmann PR, Faustini JM, Larsen DP, Shirazi MA (2008) A roughness-corrected index of relative bed stability for regional stream surveys. Geomorphology 99:150-170

Kaufmann PR, Larsen DP, Faustini JM (2009) Bed stability and sedimentation associated with human disturbances in Pacific Northwest streams. J Am Water Resour Assoc 45:434-459

Lorion CM, Kennedy BP (2008) Relationships between deforestation, riparian forest buffers and benthic macroinvertebrates in neotropical headwater streams. Freshw Biol 54:165-180

Lorion CM, Kennedy BP (2009) Riparian forest buffers mitigate the effects of deforestation on fish assemblages in tropical headwater streams. Ecol Appl 19:468-479

Mac Nally R, Wallis E, Lake PS (2011) Geometry of biodiversity patterning: assemblages of benthic macroinvertebrates at tributary confluences. Aquat Ecol 45:43-54

Macedo MN, Coe MT, DeFries R, Uriarte M, Brando PM, Neill C, Walker WS (2013) Land-use-driven stream warming in southeastern Amazonia. Philos Trans R Soc Lond B Biol Sci 368:20120153

Macedo DR, Hughes RM, Ligeiro R, Ferreira WR, Castro MA, Junqueira NT, Oliveira DR, Firmiano KR, Kaufmann PR, Pompeu PS, Callisto M (2014) The relative influence of catchment and site variables on fish and macroinvertebrate richness in cerrado biome streams. Landscape Ecol 29:1001-1016

Malhi Y, Gardner TA, Goldsmith GR, Silman MR, Zelazowski P (2014) Tropical forests in the anthropocene. Annu Rev Environ Resour 39:159

McClain ME, Elsenbeer H (2001) Terrestrial inputs to amazon streams and internal biogeochemical processing. In: McClain ME, Victoria RL, Riche JE (eds) Biogeochemistry of the Amazon basin. Oxford University Press, New York, pp 185-208

McTammany ME, Benfield EF, Webster JR (2007) Recovery of stream ecosystem metabolism from historical agriculture. J N Am Benthol Soc 26:532-545

Millennium Ecosystem Assessment (2005) Ecosystems and human well-being: wetlands and water-synthesis. World Resources Institute, Washington, D.C

Milner AM, Gloyne-Phillips IT (2005) The role of riparian vegetation and woody debris in the development of macroinvertebrate assemblages in streams. River Res Appl 21:403-420

Morton DC, DeFries RS, Shimabukuro YE, Anderson LO, Arai E, Espirito-Santo FB, Freitas F, Morisette J (2006) Cropland expansion changes deforestation dynamics in the southern Brazilian Amazon. Proc Natl Acad Sci USA 103:14637-14641

Neill C, Deegan LA, Thomas SM, Cerri CC (2001) Deforestation for pasture alters nitrogen and phosphorus in small Amazonian streams. Ecol Appl 11:1817-1828 
Neill C, Elsenbeer H, Krusche AV, Lehmann J, Markewitz D, Figueiredo RO (2006) Hydrological and biogeochemical processes in a changing Amazon: results from small watershed studies and the large-scale biosphere-atmosphere experiment. Hydrol Process 2476:2467-2476

Neill C, Chaves JE, Biggs T, Deegan LA, Elsenbeer H, Figueiredo RO, Germer S, Johnson MS, Lehmann J, Markewitz D, Piccolo MC (2011) Runoff sources and land cover change in the Amazon: an end-member mixing analysis from small watersheds. Biogeochemistry 105:7-18

Neill C, Coe MT, Riskin SH, Krusche AV, Elsenbeer H, Macedo MN, McHorney R, Lefebvre P, Davidson EA, Scheffler R, Figueira AMS, Porder S, Deegan LA (2013) Watershed responses to Amazon soya bean cropland expansion and intensification. Philos Trans R Soc Lond B Biol Sci 368:20120425

Nepstad D, McGrath D, Stickler C, Alencar A, Azevedo A, Swette B, Bezerra T, DiGiano M, Shimada J, Motta RS, Armijo E, Castello L, Brando P, Hansen MC, McGrathHorn M, Carvalho O, Hess L (2014) Slowing Amazon deforestation through public policy and interventions in beef and soy supply chains. Science 344:1118-1123

Nerbonne BA, Vondracek B (2001) Effects of local land use on physical habitat, benthic macroinvertebrates, and fish in the Whitewater River, Minnesota, USA. Environ Manag 28:87-99

Neuheimer AB, Thresher RE, Lyle JM, Semmens JM (2011) Tolerance limit for fish growth exceeded by warming waters. Nat Clim Chang 1:110-113

Newbold T, Hudson LN, Hill SLL, Contu S, Lysenko I, Senior RA, Börger L, Bennett DJ, Choimes A, Collen B, Day J, Palma AD, Díaz S, Echeverria-Londoño S, Edgar MJ, Feldman A, Garon M, Harrison MLK, Alhusseini T, Ingram DJ, Itescu Y, Kattge J, Kemp V, Kirkpatrick L, Kleyer M, Correia DLP, Martin CD, Meiri S, Novosolov M, Pan Y, Phillips HRP, Purves DW, Robinson A, Simpson J, Tuck SL, Weiher E, White HJ, Ewers RM, Mace GM, Scharlemann JPW, Purvis A (2015) Global effects of land use on local terrestrial biodiversity. Nature 520:45-50

Ortiz-Zayas JR, Lewis WM, Saunders JF, McCutchan Jr JH, Scatena FN (2005) Metabolism of a tropical rainforest stream. J N Am Benthol Soc 24:769-783

Osborne LL, Koviacic DA (1993) Riparian vegetated buffer strips in water-quality restoration and stream management. Freshw Biol 29:243-258

Paulsen SG, Mayio A, Peck DV, Stoddard JL, Tarquinio E, Holdsworth SM, Sickle JV, Yuan LL, Hawkins CP, Herlihy AT, Kaufmann PR, Barbour MT, Larsen DP, Olsen AR (2008) Condition of stream ecosystems in the US: an overview of the first national assessment. J N Am Benthol Soc 27:812-821

Peck DV, Herlihy BH, Hill RM, Hughes RM, Kaufmann PR, Klemm DJ, Lazorchak JM, McCormick FH, Peterson SA, Ringold PL, Magee T, Cappaert M (2006) Environmental monitoring and assessment program-surface waters western pilot study: field operations manual for wadeable streams. U.S. Environmental Protection Agency, Corvallis

Peres CA, Palacios E (2007) Basin wide effects of game harvest on vertebrate population densities in amazonian forests: implications for animal mediated seed dispersal. Biotropica 39:304-315
Peterjohn WT, Correll DL (1984) Nutrient dynamics in an agricultural watershed: observations on the role of a riparian forest. Ecology 65:1466-1475

Pinto BCT, Araujo FG, Rodrigues VD, Hughes RM (2009) Local and ecoregion effects on fish assemblage structure in tributaries of the Rio Paraíba do Sul, Brazil. Freshw Biol 54:2600-2615

Prasad AM, Iverson LR, Liaw A (2006) Newer classification and regression tree techniques: bagging and random forests for ecological prediction. Ecosystems 9:181199

R Core Team (2013) R: a language and environment for statistical computing. R Core Team, Vienna

Ramírez A, Pringle CM, Wantzen KM (2008) Tropical stream conservation. In: Dudgeon D (ed) Tropical stream ecology. Elsevier, London, pp 284-304

Russi D, ten Brink P, Farmer A, Badura T, Coates D, Förster J, Kumar R, Davidson N (2013) The economics of ecosystems and biodiversity for water and wetlands. Institute for European Environmental Policy (IEEP) \& Ramsar Secretariat

Sály P, Takács P, Kiss I, Bíró P, Erös T (2011) The relative influence of spatial context and catchment- and site-scale environmental factors on stream fish assemblages in a human-modified landscape. Ecol Freshw Fish 20:251-262

Satterlund DR (1972) Wildland watershed management. Wiley, New York

Smith SJ, Ellis N, Pitcher CR (2011) Conditional variable importance in $\mathrm{R}$ package extendedForest. $\mathrm{R}$ vignette, pp 2-6

Soares-Filho B, Rajão R, Macedo M, Carneiro A, Costa W, Coe M, Rodrigues H, Alencar A (2014) Cracking Brazil's forest code. Science 344:363-364

Sutherland AB, Meyer JL, Gardiner EP (2002) Effects of land cover on sediment regime and fish assemblage structure in four southern Appalachian streams. Freshw Biol 47:1791-1805

Sweeney BW (1993) Effects of streamside vegetation on macroinvertebrates in White Clay Creek. Proc Natl Acad Nat Sci Phila 144:291-340

Tedesco PA, Oberdorff T, Cornu JF, Beauchard B, Brosse S, Dürr HH, Grenouillet G, Leprieur F, Tisseuil C, Zaiss R, Hugueny B (2013) A scenario for impacts of water availability loss due to climate change on riverine fish extinction rates. J Appl Ecol 50:1105-1115

Thomson JR, Bond NR, Cunningham SC, Metzeling L, Reich P, Thompson RM, MacNally R (2012) The influences of climatic variation and vegetation on stream biota: lessons from the Big Dry in southeastern Australia. Glob Chang Biol 18:1582-1596

Uriarte M, Yackulic CB, Lim Y, Arce-Nazario JA (2011) Influence of land use on water quality in a tropical landscape: a multi-scale analysis. Landscape Ecol 26:1151-1164

Valeriano MM, Rossetti DF (2012) Topodata: Brazilian full coverage refinement of SRTM data. Appl Geogr 32:300-309

Verissimo A, Barreto P, Mattos M, Tarifa R, Uhl C (1992) Logging impacts and prospects for sustainable forest management in an old Amazonian frontier: the case of Paragominas. For Ecol Manag 55:169-199 
Vörösmarty C, Shagian D (2000) Anthropogenic disturbance of the terrestrial water cycle. Bioscience 50:753-765

Wang L, Seelbach P, Hughes R (2006a) Introduction to landscape influences on stream habitats and biological assemblages. In: Hughes RM, Wang L, Seelbach PW (eds) Landscape influences on stream habitats and biological assemblages. American Fisheries Society Symposium 48, Bethesda, pp 1-23

Wang L, Seelbach PW, Lyons J (2006b) Effects of levels of human disturbance on the influence of catchment, riparian, and reach-scale factors on fish assemblages. In: Hughes RM, Wang L, Seelbach PW (eds) Landscape influences on stream habitats and biological assemblages. American Fisheries Society Symposium 48, Bethesda, pp 199-219

Whittier T, Hughes R, Larsen P (1988) The correspondence between ecoregions and spatial patterns in stream ecosystems in Oregon. Can J Fish Aquat Sci 45:1264-1278

Wright JP, Flecker AS (2004) Deforesting the riverscape: the effects of wood on fish diversity in a Venezuelan piedmont stream. Biol Conserv 120:439-447

Yeakley JA, Maas-Hebner KG, Hughes RM (2014) Wild salmonids in the urbanizing Pacific Northwest. Springer, New York 